\title{
ПИТАННЯ СТРУКТУРНОЇ СКЛАДНОСТІ ДЛЯ ВИПАДКУ РЕГУЛЯРНОГО ЛОГІЧНОГО ДЕРЕВА
}

\section{Повхан I. Ф.}

\section{ВСТУП}

Як відомо ${ }^{1}$, довільну побудовану систему розпізнавання у вигляді дерева класифікації можна записати або в диз'юнктивній нормальній формі, або в кон'юнктивній нормальній формі; так дерево розпізнавання, яке є певним правилом класифікації, можна представити за допомогою відповідної логічної функції․․ Отже, важливими проблемами під час побудови систем розпізнавання такого типу будуть задачі синтезу логічних функцій, які еквівалентні такому дереву розпізнавання, оцінка їхньої складності, задача мінімізації отриманого дерева ${ }^{3}$. Тому дослідження $\epsilon$ логічним продовженням циклу робіт, присвячених таким важливим питанням, пов'язаним із логічними деревами класифікації, як питання побудови ${ }^{4}$, мінімізації, дослідження стійкості щодо перестановки ярусів, оцінки складності найбільшого дерева $^{5}$. Тут досліджується загальна складність граф-схемних моделей (структур логічних дерев класифікації), які конструюються в процесі навчання системи розпізнавання (логічне дерево класифікації фактично представляє собою згенеровану функцію розпізнавання) ${ }^{6}$. Для цього оцінюється складність дерева, яке використовується в схемі розгалуженого вибору ознак для розпізнавання $n-$ мірних дискретних

1 Quinlan J. R. Induction of Decision Trees. Machine Learning. 1986. № 1. P. 81-106.

${ }^{2}$ Василенко Ю.А. Концептуальна основа систем розпізнавання образів на основі метода розгалуженого вибору ознак / Ю.А. Василенко, Е.Ю. Василенко, I. Ф. Повхан. European Journal of Enterprise Technologies. 2004. № 7 (1). C. 13-15.

3 Povhan I. General scheme for constructing the most complex logical tree of classification in pattern recognition discrete objects. Електроніка та інформаційні технології : збірник наукових праць. Львів, 2019. Вип. 11. С. 112-117.

${ }^{4}$ Srikant R. Mining generalized association rules / R. Srikant, R. Agrawal. Future Generation Computer Systems. 1997. Vol. 13. № 2. P. 161-180.

${ }^{5}$ Hastie T. The Elements of Statistical Learning / Hastie T., Tibshirani R., Friedman J. Berlin : Springer, 2008. $746 \mathrm{p}$.

${ }^{6}$ Ващук Ф. Г. Проблема оцінки складності логічних дерев розпізнавання та загальний метод їх оптимізації / Ф.Г. Ващук, Ю.А. Василенко, І.Ф. Повхан. European Journal of Enterprise Technologies. 2011. № 6/4 (54). C. 24-28. 
наборів (об'єктів) ${ }^{7}$. Зауважимо, що головну увагу в дослідженні буде приділено саме верхній оцінці складності логічного дерева. Це особливо важливо у зв'язку з тим, що такі оцінки виявляють, який об'єм пам'яті має мати реальна, автономна система розпізнавання образів $^{8}$. Важливим напрямком дослідження такої проблематики в перспективі $є$ вивчення питання, як зміниться саме складне (регулярне за структурою) логічне дерево після перестановки ярусів для випадків не бінарного випадку' . Розв'язання такого питання дозволить впровадити ефективніші схеми мінімізації структур дерев класифікації - ЛДК/АДК (для алгоритмічних дерев маються на увазі структури АДК типу II) - без необхідності їх зведення до бінарного випадку ${ }^{10}$. Відзначимо, що важливим механізмом мінімізації (оптимізації структур) логічних дерев $\epsilon$ процедура перестановки ярусів (блоків) у структурі дерева, яка дозволяє досягти помітного ефекту зменшення складності логічного дерева. Водночас слід зауважити, що зі зростанням структурної складності (кількості вершин та ярусів) логічного дерева ефективність перестановки ярусів у його структурі дуже швидко зростає $\epsilon^{11}$.

На початку будемо припускати, що зафіксована деяка система дискретних ознак $P_{1}, P_{2}, \ldots, P_{n}$, причому $\left(0 \leq P_{i} \leq k_{i}-1\right),(i=1,2, \ldots, n), \mathrm{i}$ деяка система символів (міток, атрибутів) $O_{0}, O_{1}, \ldots, O_{k-1}$. Будемо також вважати, що елементарні ознаки $P_{1}, P_{2}, \ldots, P_{n}$ впорядковані (наприклад, в такому порядку, в якому вони записані тут) $)^{12}$.

${ }^{7}$ Povhan I. Designing of recognition system of discrete objects. 2016 IEEE First International Conference on Data Stream Mining \& Processing (DSMP), Lviv, 2016, Ukraine. Lviv, 2016. P. 226-231.

8 Лавер В.О. Алгоритми побудови логічних дерев класифікації в задачах розпізнавання образів / В.О. Лавер, І.Ф. Повхан. Вчені записки Таврійського національного університету. Серія «Технічні науки». 2019. Т. 30 (69). № 4. С. 100-106.

9 Ващук Ф.Г. Загальна оцінка мінімізації деревоподібних логічних структур / Ф.Г. Ващук, Ю.А. Василенко, І.Ф. Повхан. European Journal of Enterprise Technologies. 2012. № 1/4 (55). C. 29-33.

${ }^{10}$ Повхан І.Ф. Задача загальної оцінки складності максимального побудованого логічного дерева класифікації. Вісник національного технічного університету «Харьківський політехнічний інститут». 2019. № 13. С. 104-117.

11 Василенко Ю.А. Мінімізація логічних деревоподібних структур в задачах розпізнавання образів / Ю.А. Василенко, Е.Ю. Василенко, М.Й. Ковач, О.Д. Нікарович, І.Ф. Повхан. European Journal of Enterprise Technologies. 2004. № 3 (9). С. 12-16.

${ }_{12}$ Василенко Ю.А. Визначення поняття ознаки в теорії розпізнавання образів / Ю.А. Василенко, Е.Ю. Василенко, І.Ф. Повхан. Штучний Інтелект. 2002. № 4. C. 512-517. 
Відзначимо, що будемо розглядати всі регулярні логічні дерева, тобто такі, в яких у вершинах $i$ - го ярусу стоять ознаки $P_{i},(1 \leq i \leq n)$, а в вершинах $(n+1)$ - го ярусу стоять символи $O_{0}, O_{1}, \ldots, O_{k-1}-$ відповідні значення функцій $f_{R}\left(P_{1}, \ldots, P_{n}\right)$.

Нехай задане деяке регулярне логічне дерево $D$. Через $|D|$ позначимо кількість всіх різних міток, які отримуються в результаті процесу розставляння міток на логічному дереві $D$. Очевидно, що $|D|$ буде дорівнювати кількості вершин $\tilde{D}$. Задача полягає в тому, щоб серед всіх регулярних логічних дерев $D$ знайти таке логічне дерево, для якого величина $|D|$ буде найбільшою. Відзначимо, що максимальне логічне дерево позначимо через $D_{\max }$.

\section{1. Логічне дерево максимальної складності}

У межах дослідження введемо такі визначення, які будуть необхідні надалі.

Визначення 1. Під ярусом логічного дерева в дослідженні будемо розуміти горизонтальний ряд вершин графу (логічного дерева) зі змінною одного індексу. Відзначимо, що в літературі також зустрічаються терміни каскад, рівень, смуга (stripe).

Визначення 2. Самим складним логічним деревом будемо називати таке дерево, яке містить у своїй структурі максимальну кількість різних міток (вершин, функцій).

Визначення 3. Множину всіх вершин, які стоять в ярусах із номерами $i$, де $(l \leq i \leq s),(1 \leq l \leq s \leq n)$, в деякому логічному дереві будемо називати смугою (stripe).

Визначення 4. Логічне дерево (граф), що представляє $k$ - значну функцію $f\left(x_{1}, \ldots, x_{n}\right),-$ це зв'язаний граф без циклів, у некінцевих вершинах якого знаходяться змінні $x_{1}, \ldots, x_{n}$, а ребра нумеруються значеннями цих змінних. У кінцевих вершинах дерева знаходяться значення функції $f\left(x_{1}, \ldots, x_{n}\right)$. Водночас на фіксованому шляху дерева одна й та ж сама змінна зустрічається тільки один раз.

Визначення 5. Мітка стрілки, що входить у вершину дерева, характеризує функцію піддерева, визначеного цією міткою. Якщо всі вихідні стрілки деякої вершини відмічені однаковою міткою $\alpha$, то й вихідна мітка такої вершини відмічена тією ж самою міткою $\alpha$. 
Визначення 6. Якщо всі ребра, які входять у вершину логічного дерева (графа) $x_{i}$, відмічені ідентично, то вершина $x_{i}$ називається подібною.

Визначення 7. Логічне дерево (піддерево), верхня вершина якого подібна, називається особливим деревом (піддеревом). Всі інші логічні дерева й піддерева (графи) в дослідженні будемо називати неособливими.

Визначення 8. Логічне дерево (граф, функція), у вершинах кожного горизонтального ярусу якого записані однакові змінні (атрибути), називається регулярним. У протилежному випадку логічне дерево (граф, функція) називається нерегулярним.

Визначення 9. Під неоднорідним логічним деревом будемо розуміти дерево, в якого на певних ярусах можуть розташовуватись змінні різних індексів. Для однорідного дерева можлива лише структура, в якій розташовані на фіксованому ярусі змінні одного індексу.

Смугу, яка складається 3 ярусів із номерами $i,(l \leq i \leq s)$, позначимо через $D_{s}^{l}$. Через $\left|D_{s}^{l}\right|$ позначимо кількість усіх різних між собою міток у такій структурі, які стоять у смузі $D_{s}^{l}$.

На наступному етапі дослідження доведемо таке.

Твердження 1. Нехай в $i-$ му ярусі регулярного логічного дерева $D$ при різних вершинах стоять різні мітки. Тоді в полосі $D_{i}^{1}$ при різних вершинах стоять різні мітки.

Зрозуміло, що це твердження випливає безпосередньо 3 особливостей вищевказаного процесу розставляння міток у логічному дереві. Дійсно, якщо в $i$ - тому ярусі при різних вершинах стоять різні мітки, тоді при всіх вершинах ярусу $i-1$ будуть стояти різні мітки.

Крім того, всі мітки, які стоять при вершинах $(i-1)$ - го ярусу, в такому випадку, будуть відрізнятися від всіх міток, які стоять при вершинах $i, i+1, \ldots, n, n+1-$ го ярусу.

Отже, розмірковуючи аналогічним чином, можна побачити, що всі мітки $(i-2)$ - го ярусу, які стоять при різних вершинах, також розрізняються між собою та відмінні від всіх міток ярусів $i, i+1, i+2 \ldots, n, n+1$. Зрозуміло, що від ярусу $(i-2)$ ми можемо перейти до ярусу $(i-3)$, від $(i-3)$ до ярусу $(i-4)$ i так далі.

Отже, можна зробити висновок, що всі мітки $(i-j)$ - го ярусу $(1 \leq j \leq i-1)$, які стоять при різних вершинах, розрізняються між собою 
та відмінні від всіх міток (символів), які стоять при вершинах $i-j+1$, $i-j+2, \ldots, n, n+1$ - го ярусів. А це своєю чергою означає, що таке твердження доведене.

Тут слід зауважити, що наведеним вище доводиться ще й таке твердження.

Твердження 2. При умові твердження 4.1 всі мітки, які стоять в полосі $D_{i-1}$, відрізняються від всіх міток, які стоять в полосі $D_{n+1}^{i}$.

На наступному етапі перейдемо тепер безпосередньо до побудови логічного дерева $-D_{\max }$.

Нагадаємо, що всі вершини $\alpha$ в $i$ - му ярусі залежать від ознак $P_{i}, P_{i+1}, \ldots, P_{n}$. Таким чином, кожна вершина $\alpha$ в $i-$ му ярусі є деякою функцією $f_{\alpha}\left(P_{i}, P_{i+1}, \ldots, P_{n}\right)$.

Через те, що $P_{j} \in\left\{0,1,2, \ldots, k_{j}-1\right\},(j=i, i+1, \ldots, n)$ і всі функції $f_{\alpha}$ приймають значення 3 множини $\left\{O_{0}, O_{1}, \ldots, O_{k-1}\right\}$, то кількість всіх функцій вигляду $f_{\alpha}\left(P_{i}, P_{i+1}, \ldots, P_{n}\right)$ буде дорівнювати $K^{K_{i} * K_{i+1} * \ldots * K_{n}}$. Кількість вершин $i$ - го ярусу дорівнює $K_{1} * K_{2} * \ldots * K_{i-1}$.

Очевидно, що в різних вершинах $i$ - го ярусу тоді й тільки тоді можуть стояти різні функції $f_{\alpha}$ (це можна інтерпретувати як те, що в різних вершинах $i-$ го ярусу стоять різні мітки), коли виконується умова:

$$
K_{1} * K_{2} * \ldots * K_{i-1} \leq K^{K_{i}^{*} K_{i+1} * \ldots * K_{n}}
$$

Відзначимо, що, якщо $K_{1} * K_{2} * \ldots * K_{i-1}>K^{K_{i} * K_{i+1} * \ldots * K_{n}}$, тоді в $i$-му ярусі довільного логічного дерева $D$ завжди знайдуться хоча $б$ дві різні вершини з однаковими мітками.

Через те, що величини $K_{1} * K_{2} * \ldots * K_{i-1}$ і $K^{K_{i}{ }^{*} K_{i+1} * \ldots * K_{n}}$ під час зростання числа $i$, відповідно, зростають, то знайдеться таке число $m$, що:

$$
\left.\begin{array}{l}
K_{1} * K_{2} * \ldots * K_{m-1} \leq K^{K_{m} * K_{m+1} * \ldots * K_{n}} \\
K_{1} * K_{2} * \ldots * K_{m}>K^{K_{m+1}{ }^{*} K_{m+2} * \ldots * K_{n}}
\end{array}\right\},
$$

Зауважимо також, що ярус із номером $m$ в інтерпретації (1) буде ярусом злому такого логічного дерева. 
У першій частині дослідження розглянемо спочатку випадок, коли в співвідношенні (1) виконується рівність, тобто маємо таку ситуацію:

$$
K_{1} * K_{2} * \ldots * K_{m-1}=K^{K_{m} * K_{m+1} * \ldots * K_{n}} .
$$

Відзначимо, що в такому випадку кількість всіх вершин $m$ - го ярусу збігається з кількістю всіх функцій вигляду $f_{\alpha}\left(P_{i}, P_{i+1}, \ldots, P_{n}\right)$.

Логічне дерево $D_{\max }$ буде будуватися таким чином: кожній вершині $m-$ го ярусу $\alpha$ ставиться у відповідність деяка функція $f_{\alpha}\left(P_{i}, P_{i+1}, \ldots, P_{n}\right)$, водночас різним вершинам $\alpha$ і $\beta m$ - го ярусу логічного дерева ставимо у відповідність різні функції $f_{\alpha}$ i $f_{\beta}$.

У результаті отримаємо деяке логічне дерево $D^{*}$. Далі знову покажемо, що $D^{*}=D_{\max }$, тобто в логічному дереві $D^{*}$ знаходиться максимальна кількість міток.

Нехай задано довільне логічне дерево $D$. Треба показати, що $\left|D^{*}\right| \geq|D|$. На наступному етапі розіб'ємо логічні дерева $D^{*}$ і $D$ на відповідні смуги:

$$
\left(D^{*}\right)_{m-1}^{1},\left(D^{*}\right)_{n+1}^{m}, D_{m-1}^{1}, D_{n+1}^{m}
$$

3 процедури побудови логічного дерева $D^{*}$, твердження 1 i твердження 2 випливає, що жодна за міток смуги $\left(D^{*}\right)_{m-1}^{1}$ не збігається 3 жодною з міток смуги $\left(D^{*}\right)_{n+1}^{m}$. Тоді звідси отримаємо таке:

$$
\left|D^{*}\right|=\left|\left(D^{*}\right)_{m-1}^{1}\right| *\left|\left(D^{*}\right)_{n+1}^{m}\right|
$$

Аналогічно для логічного дерева $D$ будемо мати таку ситуацію:

$$
|D|=\left|D_{m-1}^{1}\right| *\left|D_{n+1}^{m}\right|,
$$

Відзначимо, що відповідно до твердження 1 у різних вершинах смуги $\left(D^{*}\right)_{m-1}^{1}$ такого логічного дерева стоять різні мітки, а це своєю чергою фактично означає, що: 


$$
\left|\left(D^{*}\right)_{m-1}^{1}\right| \geq\left|D_{m-1}^{1}\right|
$$

Очевидно, що всі мітки при вершинах $\alpha$ ярусів $m, m+1, \ldots, n+1 \epsilon$ функціями $f_{\alpha}$, які своєю чергою залежать тільки від ознак $P_{m}, P_{m+1}, \ldots, P_{n}$.

Через те, що всі мітки, які стоять на $m$ - му ярусі логічного дерева $D^{*}$, вичерпають собою всі функції, які залежать від $P_{m}, P_{m+1}, \ldots, P_{n}$ ознак, будемо мати таку ситуацію:

$$
\left|D_{n+1}^{m}\right| \leq\left|\left(D^{*}\right)_{n+1}^{m}\right|
$$

Тоді з (2), (3), (4), (5) отримаємо, що $\left|D^{*}\right| \geq|D|$ для довільного логічного дерева $D$. Це означає, що логічне дерево $D^{*} \epsilon$ максимальним деревом.

Отже, все вище сказане фактично означає, що логічне дерево структури $D^{*}$ буде самим складним логічним деревом за кількістю міток, вершин (початок розділу).

На наступному етапі дослідження підрахуємо кількість міток у структурі логічного дерева $D^{*} .3$ самої процедури побудови логічного дерева $D^{*}$ безпосередньо випливає, що:

$$
\left|D^{*}\right| \geq\left|\left(D^{*}\right)_{m}^{1}\right|
$$

Через те, що в смузі $\left(D^{*}\right)_{m}^{1}$ такого логічного дерева при різних вершинах стоять різні мітки, будемо мати таке:

$$
\left(D^{*}\right)_{m}^{1}=1+K_{1}+K_{1} * K_{2}+\ldots+K_{1} * K_{2} * \ldots * K_{m-1}=1+\sum_{j=2}^{m} K_{1} * \ldots * K_{j-1} .
$$

Звідси можна зробити висновок, що:

$$
\left|D^{*}\right|=1+\sum_{j=2}^{m} K_{1} * K_{2} * \ldots * K_{j-1},
$$

Відзначимо, що, якщо $K_{1}=K_{2}=\ldots=K_{n}=r, \quad(r \geq 2), \quad$ тоді співвідношення (6) має такий вигляд: 


$$
\left|D^{*}\right|=\frac{r^{m}-1}{r-1}
$$

Водночас співвідношення $K_{1} * K_{2}{ }^{*} \ldots * K_{m-1}=K^{K_{m} * K_{m+1}{ }^{*} \ldots{ }^{*} K_{n}}$ в цьому випадку має такий вигляд:

$$
r^{m}-1=K^{r^{n-(m-1)}}
$$

На наступному етапі, виходячи зі співвідношення (8), розглянемо таку рівність вигляду:

$$
r^{l}=K^{r^{n-l}}
$$

Для дослідження буде представляти інтерес випадок (питання), коли таке рівняння (9) має розв'язок у цілих числах $l$ та який саме розв'язок такого рівняння.

Тут слід зауважити, що рівняння (9) має не більше одного розв'язку в цілих числах $l$, бо ліва частина рівняння (9) строго зростає, а права строго спадає під час зростання відповідно числа $l$.

Далі розглянемо тільки випадок $r=K$, тому що такий випадок і представляє в основному безпосередній інтерес для практики.

Тоді співвідношення (9) має такий вигляд:

$$
K^{l}=K^{K^{n-l}}
$$

Водночас слід відзначити, що останнє співвідношення фактично еквівалентно такому виразу:

$$
l=K^{n-l}
$$

На наступному кроці дослідження зафіксуємо число $l \quad \mathrm{y}$ виразі (4.41), а далі поступово будемо міняти число $n$.

Покажемо, що співвідношення (10) тоді й тільки тоді має розв'язок у цілих числах $l$, коли $n$ має такий вигляд:

$$
n=K^{\delta}+\delta
$$

Зауважимо, що тут $\delta$ - деяке число. 
Відзначимо, що, якщо $n=K^{\delta}+\delta$, то, поклавши $l=K^{\delta}$, отримаємо таку ситуацію:

$$
K^{n-l}=K^{K^{\delta}+\delta-K^{\delta}}=K^{\delta}=l .
$$

Отже, можна зробити висновок, що у випадку, коли $n=K^{\delta}+\delta$, будемо мати таку ситуацію:

$$
m-1=l=K^{\delta} .
$$

Отже, з виразу й з рівняння (7) маємо таке:

$$
\left|D^{*}\right|=\frac{K^{m}-1}{K-1} \approx \frac{K^{m}}{K-1}=\frac{K^{K^{\delta}+1}}{K-1},
$$

Тут слід зауважити, що, якщо маємо ситуацію, коли $K=2$, тоді співвідношення (11) буде мати такий вигляд:

$$
\left|D^{*}\right| \approx 2^{2^{\delta}+1},
$$

Водночас відзначимо, що числа $\frac{K^{K^{\delta}+1}}{K-1}$ і $2^{2^{8}+1}$, відповідно, з виразів (11) і (12) відрізняються від $D^{*}$ не більше, чим на одиницю.

Отже, зважаючи на все вище сказане, легко показати, що кількість всіх вершин $d$ довільного регулярного логічного дерева $D$ при $K_{1}=K_{2}=\ldots=K_{n}=r=K$ буде дорівнювати:

$$
d=\frac{K^{n+1}-1}{K-1},
$$

Зауважимо, що при $K=2$ будемо мати таку ситуацію:

$$
d=2^{n+1}-1 \cong 2^{n+1} .
$$

На наступному етапі дослідження введемо величину $E$, яка буде дорівнювати:

$$
E=\frac{d}{\left|D^{*}\right|},
$$


Відзначимо, що величина $E$ характеризує в загальному випадку той ефект, який отримується під час переходу від логічного дерева $D$ до структури дерева $\tilde{D}$. Підставляючи у відношення (14) величини (7) i (13), отримаємо таке:

$$
E=\frac{d}{\left|D^{*}\right|}=\frac{\frac{K^{n+1}-1}{K-1}}{\frac{K^{m}-1}{K-1}}=\frac{K^{n+1}-1}{K^{m}-1} \approx \frac{K^{n+1}}{K^{m}}=K^{n-m+1}=K^{\delta} .
$$

Зауважимо, що останнє випливає 3 того факту, що $n=K^{\delta}+\delta$ i відповідно $m=K^{\delta}+1$.

Через те, що в такому випадку величина $K^{\delta}$ значно більша, чим величина $\delta$, можна покласти, що $n \approx K^{\delta}$.

Отже, виходячи $з$ усього вище сказаного, можна зробити висновок, що у випадку $K_{1}=K_{2}=\ldots=K_{n}=r=K$ i $n=K^{\delta}+\delta$ під час переходу від структури дерева $D$ до структури $\tilde{D}$ складність логічного дерева $D$ зменшується майже (приблизно) в $n$ разів.

На наступному етапі дослідження наведемо набір чисел $d$ та $\left|D^{*}\right|$ для випадку $K_{1}=K_{2}=\ldots=K_{n}=r=2$ і відповідно $n=2^{\delta}+\delta$, водночас $(\delta=1,2,3,4)$ (Табл. 1$)$.

Таблиця 1

Структури логічних дерев $\boldsymbol{r}=2,(\boldsymbol{\delta}=1,2,3,4)$

\begin{tabular}{|c|c|c|c|c|}
\hline $\boldsymbol{\delta}$ & $\boldsymbol{1}$ & $\mathbf{2}$ & $\mathbf{3}$ & $\mathbf{4}$ \\
\hline $\boldsymbol{n}=2^{\boldsymbol{\delta}}+\boldsymbol{\delta}$ & 3 & 6 & 11 & 20 \\
\hline $\boldsymbol{d}$ & 15 & 127 & 4095 & 2097151 \\
\hline$\left|\boldsymbol{D}^{*}\right|$ & 7 & 31 & 511 & 131071 \\
\hline
\end{tabular}

Далі залишилося показати, що у випадку, якщо число $n$ не можна представити у вигляді $n=K^{\delta}+\delta$, тоді рівняння (10) не має розв'язку в цілих додатних числах $l$. Тут слід зауважити, що для будь-яких цілих додатних чисел $K$ i $n,(k, n \geq 2)$ знайдеться таке єдине число $\delta$, за умови якого буде виконуватись така нерівність:

$$
K^{\delta} \leq n \leq K^{\delta+1},
$$


Відзначимо також, що, якщо виконується $n=K^{\delta}+\delta$, то $\delta$ буде задовольняти нерівність (15).

Крім того, зауважимо, що останнє випливає з того факту, що $K \geq 2$ і відповідно $K^{\delta}>\delta$.

Отже, нехай число $\delta$ задовольняє умові (15), водночас можливі три такі випадки:

$$
\begin{aligned}
& \text { 1) } n-K^{\delta}=\delta \\
& \text { 2) } n-K^{\delta}<\delta \\
& \text { 3) } n-K^{\delta}>\delta
\end{aligned}
$$

У випадку (16.1), як вже було показано вище, рівняння (10) має розв'язок у цілих додатних числах $l$.

На наступному етапі дослідження покажемо, що у випадках (16.2) та (16.3) рівняння (10) не має розв'язку в цілих числах $l$.

Спочатку для випадку (16.2) розглянемо такі числа:

$$
\begin{aligned}
& \text { a) } l=K^{\delta}+j-\delta ; \\
& \text { b) } l+1=K^{\delta}+j-\delta+1,
\end{aligned}
$$

Відзначимо, що тут $j=n-K^{\delta}$. Так відбувається у випадку (16.2) $j<\delta$ і $n=K^{\delta}+j$. На наступному етапі розрахуємо величини $K^{n-l}$ та $K^{n-(l+1)}$ при заданих числах $l$ і $l+1$ ((17.(a)) i (17.(b))):

$$
\begin{aligned}
& \text { a) } K^{n-l}=K^{K^{\delta}+j-l}=K^{K^{\delta}+j-\left(K^{\delta}+j-\delta\right)}=K^{\delta} \\
& \text { b) } K^{n-(l+1)}=K^{K^{\delta}+j-l-1}=K^{K^{\delta}+j-K^{\delta}-j+\delta-1}=K^{\delta-1}
\end{aligned}
$$

Тут слід зауважити, що через те, що за початковою умовою $j<\delta$, будемо мати таке:

$$
l=K^{\delta}+j-\delta<K^{\delta}=K^{n-l} .
$$

Але слід відзначити, що з іншого боку:

$$
\begin{gathered}
l+1=K^{\delta}+j-\delta+1 \geq K^{\delta}-(\delta-1)=K^{*} K^{\delta-1}-(\delta-1)= \\
=K^{\delta-1}+(K-1) * K^{\delta-1}-(\delta-1) \geq K^{\delta-1}+\left(K^{\delta-1}-(\delta-1)\right)> \\
>K^{\delta-1}=K^{n-(l+1)} .
\end{gathered}
$$


Тут слід зауважити, що останнє випливає 3 того факту, що за початковою умовою $K^{\delta-1}>\delta-1$.

Отже, зважаючи на все вище сказане, для випадку (16.2) будемо мати таку ситуацію:

$$
\begin{gathered}
\text { a) } \quad l<K^{n-l} \text {; } \\
\text { b) } l+1>K^{n-(l+1)} \text {, }
\end{gathered}
$$

Та 3 нерівностей (19) і 3 того факту, що ліва й права частини рівняння (10) під час збільшення числа $l$, відповідно, строго зростає й зменшується під час зменшення, випливає, що в другому випадку рівняння (10) не має розв'язку в цілих числах $l$.

На наступному етапі розглянемо випадок (16.3). Будемо мати таку ситуацію:

$$
\left.\begin{array}{c}
l=K^{\delta}+j-(\delta+1) \\
l+1=K^{\delta}+j-\delta
\end{array}\right\},
$$

Відзначимо, що тут $j=n-K^{\delta}$.

На наступному етапі по аналогії з вище сказаним розрахуємо при числах $l$ та $l+1$ відповідні значення $K^{n-l}, K^{n-(l+1)}$ :
a) $K^{n-l}=K^{K^{\delta}+j-\left(K^{\delta}+j-(\delta+1)\right)}=K^{\delta+1}$;
b) $K^{n-(l+1)}=K^{K^{\delta}+j-\left(K^{\delta}+j-\delta\right)}=K^{\delta}$,

Далі з рівнянь (20) і (21) можна отримати відповідні значення чисел $l$ i $l+1$ в такому вигляді:

$$
\begin{gathered}
\text { a) } \begin{aligned}
& l=K^{\delta}+(j-(\delta+1))<K^{\delta}+j<K^{\delta}+(K-1) * K^{\delta}= \\
&= K^{\delta+1}=K^{n-l} ; \\
& \text { b) } l+1= K^{\delta}+j-\delta>K^{\delta}=K^{n-(l+1)},
\end{aligned}
\end{gathered}
$$

Тут слід зауважити, що в (22) використовувалося таке співвідношення:

$$
(K-1) * K^{\delta}>j .
$$


Тут слід відзначити, що останнє випливає 3 того факту, що за умовою $K^{\delta} \leq n \leq K^{\delta+1}$.

Тоді зі співвідношення (22) і з того факту, що в рівнянні (10) ліва й права частини під час зростання числа $n$, відповідно, строго зростає й зменшується під час зменшення, випливає, що у випадку (16.3) рівняння (10) не має розв'язку в цілих числах $l$.

Отже, таким чином, із вищесказаного можна зробити висновок, що, коли відповідні числа $K, \delta, n$ задовольняють умовам (15), (16) і (21), то номер $m$ ярусу злому в логічному дереві $D^{*}$ знаходиться за такою формулою:

$$
m=l+1=K^{\delta}+j-\delta+1,
$$

Зауважимо, що тут $j=n-K^{\delta}$.

Відзначимо також, що, якщо відповідні числа $K, \delta, n$ задовольняють умовам (15) і (16.3), то номер $m$ ярусу злому в логічному дереві $D^{*}$ знаходиться за формулою:

$$
m=l+1=K^{\delta}+j-\delta,
$$

Відзначимо, що тут аналогічно $j=n-K^{\delta}$.

Підкреслимо, що отриманий результат має принципову важливість у задачах мінімізації логічних дерев класифікації, а відповідні підходи мають актуальність для всіх методів розпізнавання образів, в яких отримана функція класифікації може бути представлена у вигляді логічного дерева.

Логічне дерево (модель ЛДК), яке є певним правилом класифікації, можна представити за допомогою відповідної логічної функції. Отже, важливою проблемою під час побудови схеми розпізнавання (відповідного логічного дерева) такого типу буде проблема синтезу логічної функції, яка еквівалентна такому дереву розпізнавання.

Відзначимо, що зі збільшенням числа аргументів логічної функції (вислідного логічного дерева) швидко зростає складність одного 3 етапів синтезу функції - етапу мінімізації. Виходом із такого положення може бути не знаходження іiі мінімальної форми, а представлення у вигляді декомпозиції функцій (структур відповідних логічних дерев). Зауважимо, що важливими перевагами методу логічного дерева для мінімізації логічних функцій (вислідних схем класифікації) $є$ те, що з логічним деревом досить просто працювати при великій кількості аргументів. 


\section{2. Схема оцінки структурної складності логічного дерева}

На наступному етапі дослідження в приведеній оцінці складності логічного дерева (1) розглянемо випадок, коли в першому співвідношенні виконується строга нерівність, тобто:

$$
K_{1} * K_{2} * \ldots * K_{m-1}<K^{K_{m}{ }^{*} K_{m+1}{ }^{*} \ldots{ }^{*} K_{n}}
$$

Нагадаємо, що тут і надалі $K_{i}-$ кількість вершин (міток, функцій) на $i$-му ярусі, а $m$ - безпосередньо ярус злому відповідного логічного дерева, де виконується початкове співвідношення загального вигляду (1).

Далі, розглянувши в співвідношенні (1) випадок, коли в першій частині виконується строга нерівність, тобто ситуацію (25), приходимо до двох можливих варіантів:
a) $K_{1} * K_{2} * \ldots * K_{m-1} \leq K^{K_{m}{ }^{*} K_{m+1} * \ldots * K_{n}}-K^{K_{m+1}{ }^{*} K_{m+2} * \ldots * K_{n}}$;
b) $K_{1} * K_{2} * \ldots * K_{m-1}>K^{K_{m} * K_{m+1} * \ldots * K_{n}}-K^{K_{m+1} * K_{m+2} * \ldots * K_{n}}$,

Зауважимо, що аналогічно тут і далі $K_{i}$ - загальна кількість вершин (міток, функцій) на відповідному $i$-му ярусі логічного дерева.

Відзначимо також, що величина $K^{K_{m}{ }^{*} K_{m+1}{ }^{*} \ldots{ }^{*} K_{n}}-K^{K_{m+1}{ }^{*} K_{m+2}{ }^{*} \ldots{ }^{*} K_{n}} \quad \epsilon$ загальною кількістю всіх функцій вигляду $f_{\alpha}\left(P_{m}, P_{m+1}, \ldots, P_{n}\right)$, які істотно залежать від ознак $P_{m}$.

На першому етапі спочатку розглянемо випадок (26.(а)). У цьому випадку в m-му ярусі логічного дерева можна розмістити таким чином функції $f_{\alpha}\left(P_{m}, P_{m+1}, \ldots, P_{n}\right)$, що вони будуть істотно залежати від ознаки $P_{m}$, водночас у різних вершинах $a$ i $b$-го ярусу логічного дерева будуть стояти різні функції $f_{a}$ i $f_{b}$.

Розташувавши тільки що вказаним чином функції $f_{a}$ в $m$-му ярусі, отримаємо деяке логічне дерево $D^{0}$.

На наступному етапі розглянемо в логічному дереві смуги $\left(D^{0}\right)_{m}^{1} \mathrm{i}$ $\left(D^{0}\right)_{n+1}^{m+1}$. Відзначимо, що вище в параграфі було показано, що під час побудови логічного дерева $D^{0}$ множина всіх міток, які стоять у смугах $\left(D^{0}\right)_{m}^{1} \mathrm{i}\left(D^{0}\right)_{n+1}^{m+1}$, не перетинаються між собою. Крім того, в смузі $\left(D^{0}\right)_{m}^{1}$ в різних вершинах стоять різні мітки. 
Тут виникає питання, чи можна в логічному дереві $D^{0}$ в $(m+1)$-му ярусі розмітити всі функції, які залежать від ознак $P_{m+1}, \ldots, P_{n}$ (тобто ставиться питання, чи можна, не міняючи вищевказаної основної властивості логічного дерева $D^{0}$, добитися ще того, що б в $(m+1)$-му у ярусі логічного дерева $D^{0}$ стояли всі функції, які залежать від ознак $\left.P_{m+1}, \ldots, P_{n}\right)$.

Тут слід зазначити, що друге з базових співвідношень (1) вказує на той очевидний факт, що можна добитися тільки що вказаної конструкції (структури) логічного дерева $D^{0}$.

Дійсно, з нього можна бачити, що в $(m+1)$-му ярусі логічного дерева $D^{0}$ завжди знайдуться такі дві різні вершини $a$ і $b$, що $f_{a}=f_{b}$. Водночас, якщо в $(m+1)$-й ярус логічного дерева $D^{0}$ не входить деяка функція $\varphi\left(P_{m+1}, \ldots, P_{n}\right)$, тоді, замінивши у вершині $a$ функцію $f_{a}$ на $\varphi$, можна добитися того, що мітка $\varphi$ буде входити в $(m+1)$-й ярус логічного дерева $D^{0}$.

Тут слід зауважити, що за такої умови ніякі функції (мітки) 3 $(m+1)$-го ярусу не входять та основна властивість логічного дерева не міняється.

Відзначимо також той факт, що під основною властивістю логічного дерева $D^{0}$ будемо розуміти те, що в $m$-му ярусі логічного дерева $D^{0}$ в усіх вершинах стоять різні функції (мітки).

На наступному етапі, послідовно виконуючи вищевказані вставки набору невистачальних функцій $\varphi$ в $(m+1)$-й ярус, можна добитися ще того, що в $(m+1)$-му ярусі логічного дерева $D^{0}$ будуть стояти всі функції, які залежать від відповідних ознак $P_{m+1}, P_{m+2}, \ldots, P_{n}$.

Отже, зважаючи на все вище сказане, можна побудувати таке логічне дерево $D^{0}$, що виконуються такі умови:

1) множина міток (функцій), які стоять у смугах $\left(D^{0}\right)_{m}^{1}$ i $\left(D^{0}\right)_{n+1}^{m+1}$ логічного дерева $D^{0}$, не перетинається між собою;

2) у різних вершинах смуги $\left(D^{0}\right)_{m}^{1}$ стоять різні мітки;

3) мітки, які стоять у смузі $\left(D^{0}\right)_{n+1}^{m+1}, \epsilon$ всіма функціями, які залежать від аргументів $P_{m+1}, P_{m+2}, \ldots, P_{n}$. 
На наступному етапі, застосовуючи до логічного дерева $D^{0}$ такий самий підхід (процедуру), що й до дерева $D^{*} 3$ першої частини параграфу дослідження, можна показати, що логічне дерево $D^{0} \epsilon$ максимальним деревом (деревом максимальної складності).

Відзначимо, що під час доведення максимальності логічного дерева $D^{0}$, єдина невелика різниця полягає в тому, що логічне дерево $D^{*}$ розбивається на смуги $\left(D^{*}\right)_{m}^{1}$ i $\left(D^{*}\right)_{n+1}^{m+1}$, а логічне дерево $D^{0}$ треба розбивати на відповідні смуги $\left(D^{0}\right)_{m}^{1} \mathrm{i}\left(D^{0}\right)_{n+1}^{m+1}$.

Далі розрахуємо величину $\left|D^{0}\right|$. Виходячи з всього вищесказаного, зафіксуємо таке:

$$
\begin{gathered}
\left|D^{0}\right|=\left|\left(D^{0}\right)_{m}^{1}\right|+\left|\left(D^{0}\right)_{n+1}^{m+1}\right| ; \\
\left|\left(D^{0}\right)_{m}^{1}\right|=1+K_{1}+K_{1}^{*} K_{2}+\ldots+K_{1}^{*} K_{2} * \ldots * K_{m-1} ; \\
\left|\left(D^{0}\right)_{n+1}^{m+1}\right|=K^{K_{m+1} * \ldots * K_{n}} .
\end{gathered}
$$

Отже, з таких величин можна отримати:

$$
\left|D^{0}\right|=1+\sum_{j+1}^{m-1} K_{1} * K_{2} * \ldots * K_{1}+K_{j}+K^{K_{m+1}{ }^{*} K_{m+2} * \ldots * K_{n}},
$$

На наступному етапі дослідження розглянемо в (26) другий випадок - (26.(b)).

Відзначимо, що в цьому випадку максимальне логічне дерево $\bar{D}$ будемо будувати таким чином.

В $m$ - му ярусі розмістимо в різних вершинах різні функції, які залежать від ознак $P_{m+1}, P_{m+2}, \ldots, P_{n}$. Зауважимо, що останнє можливе завдяки співвідношенню (26.(b)), водночас можливо в $m$ - му ярусі логічного дерева $\bar{D}$ розмістити всі функції вигляду $f_{a}\left(P_{m+1}, P_{m+2}, \ldots, P_{n}\right)$, які істотно залежать від ознаки $P_{m}$.

Далі будемо вважати, що в логічному дереві $\bar{D}$ таке розміщення вже існує (комбінація міток). Тоді завдяки останньому розміщенню в $(m+1)$ - му ярусі логічного дерева $\bar{D}$ будуть присутні всі функції, які залежать від ознак $P_{m+1}, P_{m+2}, \ldots, P_{n}$. 
Дійсно, нехай $\varphi\left(P_{m+1}, P_{m+2}, \ldots, P_{n}\right)$ - довільна функція, яка залежать від елементарних ознак $P_{m+1}, P_{m+2}, \ldots, P_{n}$. Візьмемо ще одну функцію $\psi\left(P_{m+1}, P_{m+2}, \ldots, P_{n}\right)$, відмінну від функції $\varphi$. Побудуємо таку логічну функцію $f\left(P_{m}, P_{m+1}, \ldots, P_{n}\right)$ вигляду:

$$
\begin{aligned}
& f\left(0, P_{m+1}, P_{m+2}, \ldots, P_{n}\right)=\varphi\left(P_{m+1}, P_{m+2}, \ldots, P_{n}\right) ; \\
& f\left(j, P_{m+1}, P_{m+2}, \ldots, P_{n}\right)=\psi\left(P_{m+1}, P_{m+2}, \ldots, P_{n}\right),
\end{aligned}
$$

Відзначимо, що тут $\left(1 \leq j \leq K_{m}-1\right)$. Очевидно, що $f$ буде істотно залежною від ознаки $P_{m}$. Отже, функція $f$ буде входити в $m$-й ярус логічного дерева $\bar{D}$, а звідси й 3 (28) можна зробити висновок, що функція $\varphi$ буде входити в $(m+1)$-й ярус логічного дерева $\bar{D}$.

На наступному етапі розіб'ємо логічне дерево $\bar{D}$ на дві частини (смуги): $(\bar{D})_{m-1}^{1}$ i $(\bar{D})_{n+1}^{m}$. Зауважимо, що з побудови логічного дерева $\bar{D}$ випливають такі властивості:

1) у різних вершинах смуги $(\bar{D})_{m-1}^{1}$ логічного дерева $\bar{D}$ стоять різні функції (мітки);

2) множина міток, які стоять у смугах $(\bar{D})_{m-1}^{1} \mathrm{i}(\bar{D})_{n+1}^{m}$ логічного дерева $\bar{D}$, не перетинається між собою;

3) усі мітки, які стоять у смузі $(\bar{D})_{n+1}^{m}$ відповідного логічного дерева $\bar{D}$, вичерпають всі функції, які своєю чергою залежать від набору елементарних ознак $P_{m}, P_{m+1}, \ldots, P_{n}$.

Далі, використовуючи тільки що приведені властивості й застосовуючи ті самі судження, що й під час доведення максимального логічного дерева $D^{*}$ з першої частини параграфу, легко переконатися, що логічне дерево $\bar{D} €$ максимальним деревом за своєю структурою (логічне дерево максимальної складності).

На наступному етапі підрахуємо величину $|\bar{D}|$ для відповідного логічного дерева $\bar{D}$. Отже, виходячи 3 вищесказаних властивостей логічного дерева $\bar{D}$, можна записати таке:

$$
|\bar{D}|=\left|(\bar{D})_{m-1}^{1}\right|+\left|(\bar{D})_{n+1}^{m}\right| ;
$$




$$
\begin{gathered}
\left|(\bar{D})_{m-1}^{1}\right|=1+K_{1}+K_{1} * K_{2}+\ldots+K_{1} * K_{2} * \ldots K_{m-1}= \\
=1+\sum_{j=1}^{m-2} K_{1} * K_{2} * \ldots * K_{j} ; \\
\left|(\bar{D})_{n+1}^{m}\right|=K^{K_{m}{ }^{*} K_{m+1} * \ldots * K_{n}} .
\end{gathered}
$$

Отже, зважаючи на все вище сказане, в підсумку будемо мати таку ситуацію щодо величини $|\bar{D}|$ :

$$
|\bar{D}|=1+\sum_{j=1}^{m-2} K_{1} * K_{2} * \ldots * K_{j}+K^{K_{m}{ }^{*} K_{m+1} * \ldots * K_{n}}
$$

Далі, резюмуючи все вищесказане, можна привести таку формулу для розрахунку $\left|D_{\max }\right|:$

$$
\left|D_{\max }\right|=1+\sum_{j=1}^{m-1} K_{1} * K_{2} * \ldots * K_{j},
$$

Відзначимо, що формула (29) буде справедлива, якщо виконується така умова:

$$
\begin{gathered}
K_{1} * K_{2} * \ldots * K_{m-1}=K^{K_{m} * K_{m+1} * \ldots * K_{n}} . \\
\left|D_{\max }\right|=1+\sum_{j=1}^{m-1} K_{1} * K_{2} * \ldots * K_{j}+K^{K_{m+1} * K_{m+2} * \ldots * K_{n}},
\end{gathered}
$$

Зауважимо, що формула (30) буде справедлива, якщо виконуються такі умови:

$$
\begin{gathered}
K_{1} * K_{2} * \ldots * K_{m-1}<K^{K_{m}{ }^{*} K_{m+1}{ }^{*} \ldots{ }^{*} K_{n}} ; \\
K_{1} * K_{2} * \ldots * K_{m-1} * K_{m}>K^{K_{m+1} * K_{m+2} * \ldots * K_{n}} ; \\
K_{1} * K_{2} * \ldots * K_{m-1} \leq K^{K_{m} * K_{m+1} * \ldots * K_{n}}-K^{K_{m+1} * K_{m+2} * \ldots * K_{n}} . \\
\left|D_{\max }\right|=1+\sum_{j=1}^{m-2} K_{1} * K_{2} * \ldots * K_{j}+K^{K_{m}{ }^{*} K_{m+1} * \ldots * K_{n}},
\end{gathered}
$$


Зазначимо, що формула (31) буде справедлива, якщо виконуються такі умови:

$$
\begin{gathered}
K_{1} * K_{2} * \ldots * K_{m-1}<K^{K_{m}{ }^{*} K_{m+1} * \ldots * K_{n}} ; \\
K_{1} * K_{2} * \ldots * K_{m-1} * K_{m}>K^{K_{m+1} * K_{m+2} * \ldots * K_{n}} ; \\
K_{1} * K_{2} * \ldots * K_{m-1}>K^{K_{m} * K_{m+1} * \ldots * K_{n}}-K^{K_{m+1} * K_{m+2} * \ldots * K_{n}} .
\end{gathered}
$$

На наступному етапі дослідження припустимо, що маємо таку ситуацію:

$$
K_{1}=K_{2}=\ldots=K_{n}=K \geq 2 .
$$

Далі покажемо, що в цьому випадку буде виконуватися співвідношення (26.(а)). Зауважимо, що в цьому випадку для дослідження буде цікавим тільки випадок, коли виконується нерівність:

$$
K_{1} * K_{2} * \ldots * K_{m-1}<K^{K_{m} * K_{m+1} * \ldots * K_{n}} .
$$

Тобто випадок, коли маємо ситуацію, що:

$$
K^{m-1}<K^{n-(m-1)} .
$$

Тут слід відзначити, що випадок, коли $K^{m-1}=K^{n-(m-1)}$, був розглянутий у дослідженні раніше.

Отже, з усього наведеного вище випливає, що при $K^{m-1}<K^{n-(m-1)}$ можливі такі два варіанти:
a) $j<\delta$;
б) $j>\delta$,

Зауважимо, що тут $\delta$ - таке число, що для нього виконується відповідна нерівність:

$$
K^{\delta} \leq n \leq K^{\delta+1} .
$$

Тобто число $\delta \in$ ярусом злому логічного дерева, яке розглядається.

$$
K^{\delta} \leq n<\delta,\left(j=n-K^{\delta}\right) .
$$


Тут слід відзначити, що у випадку виконання умови (32.(a)) i зважаючи на представлене в дослідженні визначення ярусу злому логічного дерева, будемо мати таку ситуацію:

$$
\begin{gathered}
K_{1} * K_{2} * \ldots * K_{m-1}=K^{K_{m-1}}=K^{l}=K^{K^{\delta}+j-\delta} ; \\
K_{m} * K_{m+1} * \ldots * K_{n}=K^{n-(m-1)}=K^{n-l}=K^{\delta} ; \\
K_{m+1} * K_{m+2} * \ldots * K_{n}=K^{n-m}=K^{n-(l+1)}=K^{\delta-1},
\end{gathered}
$$

На наступному етапі дослідження можемо зробити висновок, що 3 відношення (33) випливає таке:

$$
\begin{gathered}
K^{K_{m}{ }^{*} \ldots{ }^{*} K_{n}}-K^{K_{m+1}{ }^{*} \ldots{ }^{*} K_{n}}=K^{K^{\delta}}-K^{K^{\delta-1}}=K^{K^{\delta}} *\left(1-K^{K^{\delta-1}-K^{\delta}}\right)= \\
=K^{K^{\delta}} *\left(1-\frac{1}{K^{K^{\delta-1} *(K-1)}}\right) \geq K^{K^{\delta}} *\left(1-\frac{1}{K}\right),
\end{gathered}
$$

Далі з формул (33) в (32) будемо мати таку ситуацію:

$$
K_{m} * K_{m+1} * \ldots * K_{n}=K^{K^{\delta}+j-\delta} \leq K^{K^{\delta}-1}=K^{K^{\delta}} * \frac{1}{K},
$$

Тут слід зауважити, що через те, що за умовою $K \geq 2$, будемо мати таку ситуацію:

$$
\frac{1}{K}=1-\frac{K-1}{K} \leq 1-\frac{1}{K} .
$$

Отже, з формул (34) і (35) будемо мати таке:

$$
K^{K_{m}{ }^{*} \ldots K_{n}}-K^{K_{m+1}{ }^{*} \ldots{ }^{*} K_{n}} \geq K_{1} * \ldots * K_{m-1} .
$$

Далі у випадку виконання умови (32.(b)) і зважаючи на представлене в дослідженні визначення ярусу злому логічного дерева, будемо мати таку ситуацію:

$$
\begin{gathered}
K_{1} * K_{2} * \ldots * K_{m-1}=K^{m-1}=K^{l}=K^{K^{\delta}+j-(\delta+1)} \\
K_{m} * K_{m+1} * \ldots * K_{n}=K^{n-(m-1)}=K^{n-l}=K^{\delta-1} \\
K_{m+1} * K_{m+2} * \ldots * K_{n}=K^{n-m}=K^{n-(l+1)}=K^{\delta},
\end{gathered}
$$


На наступному етапі дослідження можемо зробити висновок, що 3 відношення (36) випливає таке:

$$
K^{K_{m}{ }^{*} \ldots{ }^{*} K_{n}}-K^{K_{m+1}{ }^{*} \ldots K_{n}}=K^{K^{\delta+1}}-K^{K^{\delta} *}\left(K^{K^{\delta} *(K-1)}-1\right),
$$

Далі з попередніх формул (36), (32.(b)) і того факту, що за умовою $\delta>0$ та $j<K^{\delta} *(K-1)$, будемо мати таке:

$$
\begin{array}{r}
K_{m} * K_{m+1} * \ldots * K_{n}=K^{K^{\delta}+j-(\delta+1)} \leq \\
\leq K^{K^{\delta}} * K^{j-1}<K^{K^{\delta}} * K^{K^{\delta} *(K-1)-1},
\end{array}
$$

Тут слід зауважити, що через те, що за умовою $K \geq 2$ та $\delta \geq 0$, будемо мати таку ситуацію:

$$
K^{K^{*(K-1)}}-1 \geq K^{K^{\delta *(K-1)-1}} .
$$

Відзначимо, що це дійсно випливає з такого:

$$
\begin{aligned}
& K^{K^{\delta} *(K-1)}=K^{K^{\delta} *(K-1)} *\left(1-\frac{1}{K^{K^{\delta} *(K-1)}}\right) \geq \frac{1}{K^{K^{\delta} *(K-1)}} \geq \\
& \geq K^{K^{\delta} *(K-1)} *\left(1-\frac{1}{K}\right) \geq K^{K^{\delta} *(K-1)} *\left(1-\frac{K-1}{K}\right)= \\
& =K^{K^{\delta *}(K-1)} * \frac{1}{K}=K^{K^{\delta *(K-1)-1}} \text {, }
\end{aligned}
$$

На наступному етапі дослідження 3 формул (37), (38) і (39) отримаємо таке:

$$
K^{K_{m}{ }^{*} \ldots K_{n}}-K^{K_{m+1} * \ldots * K_{n}} \geq K_{1} * \ldots * K_{m-1},
$$

Отже, зафіксуємо таке: вище в параграфі було показано, що у випадку $K_{1}=K_{2}=\ldots=K_{n}=K \geq 2$ й $K_{1} * K_{2} * \ldots * K_{m-1}<K^{K_{m} * K_{m+1} * . . * K_{n}}$ завжди виконується співвідношення (40).

Звідси й з відношення (30) отримаємо такі формули для розрахунку величини $\left|D_{\max }\right|$ у випадку $K_{1}=K_{2}=\ldots=K_{n}=K \geq 2$ :

$$
\left|D_{\max }\right|=\frac{K^{K^{\delta}+1}-1}{K-1}
$$


Відзначимо, що формула (41) буде справедлива, якщо виконується така умова:

$$
\begin{gathered}
n=K^{\delta}+\delta . \\
\left|D_{\max }\right|=\frac{K^{K^{\delta}+j-\delta+1}-1}{K-1}+K^{K^{\delta-1}},
\end{gathered}
$$

Зауважимо, що формула (42) буде справедлива, якщо виконується така умова:

$$
\begin{array}{r}
n=K^{\delta}+\delta \text { та } j<\delta . \\
\left|D_{\max }\right|=\frac{K^{K^{\delta}+j-\delta}}{K-1}+K^{K^{\delta}},
\end{array}
$$

Зазначимо, що формула (43) буде справедлива, якщо виконується така умова:

$$
n=K^{\delta}+j \text { та } K^{\delta} *(K-1)>j>\delta .
$$

Зауважимо, що у випадку $K_{1}=K_{2}=\ldots=K_{n}=K=2$ отримаємо таке:

$$
\left|D_{\max }\right|=K^{2^{\S}+1}-1
$$

Відзначимо, що така формула буде справедлива, якщо виконується така умова:

$$
\begin{gathered}
n=2^{\delta}+\delta . \\
\left|D_{\max }\right|=2^{2^{\delta}+1}-1 .
\end{gathered}
$$

Зауважимо, що така формула буде справедлива, якщо виконується аналогічна умова, що і $з n=2^{\delta}+\delta$.

$$
\left|D_{\max }\right|=2^{2^{\delta}+j-\delta-1}+2^{2^{\delta-1}}-1,
$$


Зазначимо, що формула (44) буде справедлива, якщо виконується така умова:

$$
\begin{gathered}
n=2^{\delta}+j \text { та } j<\delta . \\
\left|D_{\max }\right|=2^{2^{\delta}+j-\delta}-1+2^{2^{\delta}} .
\end{gathered}
$$

Зауважимо, що така формула буде справедлива, якщо виконується така умова:

$$
n=2^{\delta}+j \text { та } 2>j>\delta .
$$

Так, виходячи $з$ формул (41), (42), (43), наведених вище, можна запропонувати такий спосіб розрахунку величини $\left|D_{\max }\right|$ при виконанні умови $K_{1}=K_{2}=\ldots=K_{n}=K \geq 2$.

Алгоритм розрахунку величини $\left|D_{\max }\right|$ довільного логічного дерева.

1) на першому етапі знаходимо таке число $\delta$, для якого виконується умова $K^{\delta} \leq n \leq K^{\delta+1}$;

2) на другому етапі розраховуємо величину $j=n-K^{\delta}$;

3) на третьому етапі, в залежності від випадків $j=\delta, j<\delta$ i $j>\delta$, розрахунок величини $\left|D_{\max }\right|$ проводиться, відповідно, за наведеними вище формулами (41), (42), (44).

\section{ВИСНОВКИ}

Отже, зважаючи на все вище сказане в дослідженні, можна зафіксувати такі пункти:

1. На основі запропонованих формул (41-43) можна розрахувати й привести відповідні вибіркові значення структурної складності $d$ i $\left|D_{\max }\right|$ :

$$
\begin{gathered}
\left(n=5, d=63,\left|D_{\max }\right|=19\right) ;\left(n=10, d=2047,\left|D_{\max }\right|=271\right) ; \\
\left(n=15, d=65535,\left|D_{\max }\right|=4349\right) ;\left(n=20, d=2097151,\left|D_{\max }\right|=131071\right) .
\end{gathered}
$$

Зауважимо, що тут $K_{1}=K_{2}=\ldots=K_{n}=K=2$, а $d$ позначає кількість всіх вершин регулярного логічного дерева $D$ при відповідному значенні величини $n$.

2. Показані особливості представлення функцій розпізнавання у вигляді логічних дерев, водночас структура дерева в більшості випадків 
не оптимальна й дозволяє наступний етап мінімізації (складність вислідного дерева класифікації найбільша або наближається до неї).

3. Досліджене регулярне логічне дерево й визначено ярус злому такої структури, що дозволяє оцінити рівень складності відносно до можливості мінімізації такого логічного дерева.

4. Вище в дослідженні були представлені числові оцінки й загальна схема оцінки складності дослідженого регулярного логічного дерева.

Виведені числові оцінки й загальна схема оцінки складності логічного дерева в перспективі дозволяють розробити ефективні моделі схем мінімізації логічних дерев класифікації, а отже й отримати мінімальну форму системи розпізнавання дискретних об'єктів.

\section{АНОТАЦІЯ}

На основі функціоналів, які запропоновані в дослідженні, можна розрахувати й привести відповідні вибіркові значення параметрів структурної складності моделей логічних дерев класифікації. Показані особливості представлення функцій розпізнавання у вигляді логічних дерев, водночас структура дерева в більшості випадків не оптимальна й дозволяє наступний етап мінімізації (складність вислідного дерева класифікації найбільша або наближається до неї). Досліджено структуру регулярного логічного дерева й визначено ярус злому такої конструкції, що дозволяє оцінити рівень складності відносно до можливості мінімізації такого логічного дерева. У роботі були представлені числові оцінки й загальна схема оцінки складності дослідженого регулярного логічного дерева. Виведені числові оцінки й загальна схема оцінки складності логічного дерева, що в перспективі дозволяє розробити ефективні моделі схем мінімізації логічних дерев класифікації, а отже й отримати мінімальну форму системи розпізнавання дискретних об’єктів (моделі логічного дерева класифікації).

\section{ЛITЕРАТУРА}

1. Quinlan J. R. Induction of Decision Trees. Machine Learning. 1986. № 1. P. 81-106.

2. Василенко Ю. А. Концептуальна основа систем розпізнавання образів на основі метода розгалуженого вибору ознак / Ю.А. Василенко, Е. Ю. Василенко, І. Ф. Повхан. European Journal of Enterprise Technologies. 2004. № 7 (1). C. 13-15.

3. Povhan I. General scheme for constructing the most complex logical tree of classification in pattern recognition discrete objects. Електроніка та інформаційні технології : збірник наукових праць. Львів, 2019. Вип. 11. C. 112-117. 
4. Srikant R. Mining generalized association rules / R. Srikant, R. Agrawal. Future Generation Computer Systems. 1997. Vol. 13. № 2. P. 161-180.

5. Hastie T. The Elements of Statistical Learning / T. Hastie, R. Tibshirani, J. Friedman. Berlin : Springer, 2008. 746 p.

6. Povhan I. Designing of recognition system of discrete objects. 2016 IEEE First International Conference on Data Stream Mining \& Processing (DSMP), Lviv, 2016, Ukraine. Lviv, 2016. P. 226-231.

7. Повхан І. Ф. Задача загальної оцінки складності максимального побудованого логічного дерева класифікації. Вісник національного технічного університету «Харьківський політехнічний інститут». 2019. № 13. С. 104-117.

8. Василенко Ю. А. Метод розгалуженого вибору ознак в математичному конструюванні багаторівневих систем розпізнавання образів / Ю.А. Василенко, Е.Ю. Василенко, І.Ф. Повхан. Штучний Інтелект. 2003. № 7. С. 246-249.

9. Повхан І. Ф. Проблема функціональної оцінки навчальної вибірки в задачах розпізнавання дискретних об'єктів. Вчені записки Таврійського начіонального університету. Серія "Технічні науки». 2018. T. 29 (68). № 6. C. 217-222.

10. Василенко Ю.А. Визначення поняття ознаки в теорії розпізнавання образів / Ю.А. Василенко, Е.Ю. Василенко, І. Ф. Повхан. Штучний Інтелект. 2002. № 4. С. 512-517.

11. Лавер В.О. Алгоритми побудови логічних дерев класифікації в задачах розпізнавання образів / В.О. Лавер, І.Ф. Повхан. Вчені записки Таврійського наиіонального університету. Серія «Технічні науки». 2019. T. 30 (69). № 4. C. 100-106.

12. Deng H. Bias of importance measures for multi-valued attributes and solutions / H. Deng, G. Runger, E. Tuv. Proceedings of the 21st International Conference on Artificial Neural Networks (ICANN). 2011. P. 293-300.

13. Повхан І.Ф. Особливості випадкових логічних дерев класифікації в задачах розпізнавання образів. Вчені записки Таврійського національного університету. Серія "Технічні науки». 2019. T. 30 (69). № 5. С. 152-161.

14. Ващук Ф.Г. Проблема оцінки складності логічних дерев розпізнавання та загальний метод їх оптимізації / Ф.Г. Ващук, Ю.А. Василенко, І.Ф. Повхан. European Journal of Enterprise Technologies. 2011. № 6/4 (54). C. 24-28.

15. Ващук Ф.Г. Загальна оцінка мінімізації деревоподібних логічних структур / Ф.Г. Ващук, Ю.А. Василенко, І.Ф. Повхан. European Journal of Enterprise Technologies. 2012. № 1/4 (55). C. 29-33. 
16. Василенко Ю.А. Мінімізація логічних деревоподібних структур в задачах розпізнавання образів / Ю.А. Василенко, Е.Ю. Василенко, М.Й. Ковач, О.Д. Нікарович, І.Ф. Повхан. European Journal of Enterprise Technologies. 2004. № 3 (9). С. 12-16.

\section{Information about author:}

Povkhan I. F.,

Candidate of Technical Sciences, Associate Professor of Chair of Software System

Uzhgorod National University 89-B, Zankoveckaya str., Uzhgorod, 88000, Ukraine 